\title{
Ambiente, pessoas e labor: APLs além do desenvolvimento econômico na mineração de opalas em Pedro II, no Piauí
}

\author{
Environment, people and work, clusters beyond economic development in the \\ opal mining in Pedro II, Piauí
}

\author{
Bruno Milanez ${ }^{1}$ \\ José Antonio Puppim²
}

\begin{abstract}
Resumo
Este artigo propõe que políticas públicas voltadas para arranjos produtivos loocais (APLs) têm um importante potencial para melhorar o desempenho dos pequenos garimpos e minas de gemas no Brasil, desde que integrem questões ambientais e sociais às ações voltadas ao desenvolvimento econômico. Esse argumento é baseado no estudo empírico dos problemas socioambientais enfrentados pelo APL de opalas em Pedro II, no Piauí. O estudo foi desenvolvido através da metodologia de estudos de caso, envolvendo extensa revisão bibliográfica, pesquisa em documentos do APL e entrevistas com vários integrantes do arranjo. Entre os resultados da pesquisa, foram identificadas algumas questões que vêm inibindo o pleno desenvolvimento do $A P L$, como as condições de trabalho e a mitigação dos impactos ambientais, cujas melhorias dependem de recursos humanos e financeiros, bem como de vontade política. Entretanto, um segundo grupo de questões suscita um debate mais amplo, que envolve outros APLs de base mineral, como o equilíbrio de forças entre os diferentes elos da cadeia produtiva, a criação de alternativas econômicas no caso da exaustão das jazidas existentes, a tributação das atividades minerais e o redesenho dos procedimentos de licenciamento de atividades minerais, para que estas se dêem de maneira mais sustentável.
\end{abstract}

Palavras-chave: arranjo produtivo local; mineração; gemas; desenvolvimento local.

\begin{abstract}
This article argues that if public policies designed to stimulate clusters incorporate social and environmental concerns they are likely to have a relevant role in improving the performance of small scale gem mining in Brazil. This argument is based on empirical studies of the social and environmental problems faced by the opal cluster in Pedro II, Piauí state. The research has been developed as a case study, including an extensive literature review, consultation of official documents and reports, and interviews with key stakeholders. The results suggest that some issues are limiting the development of the cluster, including labour conditions and remediation of environmental impacts. Nevertheless, there are indications that such problems could be corrected, depending on human resources, money and political will. On the other hand, it is also argued that if decision makers desire to make this cluster really sustainable, they will have to debate a second group of issues, such as balance between different actors of the production chain, economic activities that could substitute mining in the case of resource shortage, redistribution of tax revenues and redesign of licensing procedures.
\end{abstract}

Keywords: cluster; mining; gems; local development.

\footnotetext{
1 Engenheiro de Produção pela Universidade Federal do Rio de Janeiro(UFRJ), Mestre em Engenharia Urbana pela Universidade Federal de São Carlos (UFSCar), Doutor em Política Ambiental (Lincoln University). Técnico de Planejamento de Pesquisa no Instituto de Pesquisa Econômica Aplicada (IPEA).Endereço: Instituto de Pesquisa Econômica Aplicada, SBS Quadra 1 - Bloco J - Ed. BNDES, Brasília - Distrito Federal - CEP: 70076-900.Email: bruno.milanez@ipea.gov.br

2 Doutor em Planejamento - Massachusetts Institute Of Technology, EUA . Pesquisador Sênior, Instituto de Estudos Avançados (IAS), Universidade das Nações Unidas (UNU-LAS), Japão. Endereço: United Nations University Institute of Advanced Studies 6F International Organizations Center PacificoYokohama 1-1-1 Minato Mirai, Nishi-ku - Yokohama 220-8502 -Japan. E-mail: joseantonio_puppimdeoliveira@yahoo.com
}

Artigo submetido em outubro e aceito em dezembro de 2008 


\section{Introdução}

Este artigo apresenta uma discussão sobre a formação e o quadro atual do arranjo produtivo local (APL) de opalas em Pedro II, município do estado do Piauí. Ao contrário da maior parte dos documentos existentes sobre a opala de Pedro II, este estudo não se preocupa com a geologia desse mineral, mas recorre a pontos de vista da administração pública e da ciência política para avaliar aspectos econômicos, sociais e organizacionais de sua cadeira produtiva. Dessa forma, ele tenta descrever como se configurou o atual APL e quais os principais desafios a serem enfrentados pelos seus integrantes. Nesse sentido, o principal argumento do artigo é o de que políticas públicas voltadas para APLs podem ir além da preocupação com o desenvolvimento econômico e a inovação tecnológica, incorporando também questões relacionadas ao meio ambiente e à saúde e segurança dos trabalhadores.

A elaboração do artigo foi motivada por questões sociais e teóricas. Do ponto de vista da relevância social, partiu-se do pressuposto de que boa parte da mineração de gemas no Brasil e de outros países em desenvolvimento é feita por garimpeiros ou por pequenas empresas de mineração, muitos deles no setor informal.

A Organização Internacional do Trabalho (OIT) estimou, em 1999, que existiam mais de 13 milhões de pequenos mineradores em todo o mundo, a maioria deles em países em desenvolvimento (HINTON et al, 2003, VEIGA, 2001). Embora essas atividades gerem benefícios econômicos, também são acompanhadas por muitos impactos negativos ambientais e sociais, devido às tecnologias ineficientes e degradadoras utilizadas, que colocam em risco a vida dos garimpeiros, a qualidade de vida da comunidade ao redor e a integridade do meio ambiente local.

Considerando a perspectiva teórica, este estudo se propõe a colaborar em dois campos do conhecimento. Em primeiro lugar, contribui para a literatura sobre pequenas e microempresas (PMEs) e seus APLs (AMORIM, 1998; LASTRES et al, 2003; SCHMITZ; NADVI, 1999), buscando discutir como tais APLs poderiam não só promover o desenvolvimento tecnológico, mas também melhorar a qualidade ambiental, laboral e de saúde e segurança dos trabalhadores de uma localidade (aqui, os garimpeiros são considerados microempresas minerais). Como segunda contribuição teórica, adota a perspectiva das ciências sociais aplicadas para estudar sob um novo enfoque (o socioambiental) os APLs de um setor sobre o qual pouco se sabe (o garimpo de gemas). Nesse sentido, cabe observar que apesar das extensas pesquisas sobre os efeitos socioambientais da grande mineração (ALI, 2003), pouco tem sido escrito sobre como a pequena mineração tem impactado a vida das pessoas e o meio ambiente, levando-se em conta que o pouco material disponível se concentra nos setores de diamantes e de ouro (HILSON, 2003, HILTON et al, 2003, VEIGA, 2001), ignorando o setor de gemas, dos quais o Brasil é um dos maiores produtores mundiais.

A pesquisa foi feita através da metodologia de estudos de caso (YIN, 1994). Estes estudos envolveram pesquisa de campo detalhadas sobre o funcionamento do APL - incluindo entrevistas com seus trabalhadores e suas empresas formais e informais - e o das organizações que lhe dão suporte. Entre essas instituições foram contatadas: o Serviço de Apoio às Micro e Pequenas Empresas (Sebrae), sindicatos, comerciantes, governos municipal e estadual, universidades, a Secretaria Estadual de Meio Ambiente e Recursos Naturais (Semar) e o Instituto Brasileiro do Meio Ambiente e dos Recursos Naturais Renováveis (Ibama), em julho e agosto de 2007. A pesquisa de campo envolveu a coleta de material bibliográfico e de dados, além de entrevistas semiestruturadas com os principais atores sociais envolvidos com o APL (WEISS, 1995), usando também surveys transcritas oralmente (OISHI, 2002). O trabalho de campo identificou quais os obstáculos para o desenvolvimento socioambiental e que estratégias os atores locais têm utilizado para tentar superar esses obstáculos.

Para realizar esse debate o artigo se estrutura em seis partes. Primeiro, é levantada uma breve discussão conceitual sobre as vantagens potenciais dos APLs como indutores de inovação e de melhorias sociais e ambientais no contexto das pequenas e médias empresas. Em seguida, apresentam-se de forma geral, algumas características do garimpo de gemas no Brasil. Na seção seguinte, descreve-se o caso do APL de opalas em Pedro II, descrição que inclui uma breve explicação sobre a opala, alguns indicadores socioeconômicos de 
Pedro II, um histórico da exploração da opala nesse município e algumas iniciativas tomadas pelo APL. Seguese, então, uma análise dos principais desafios a serem enfrentados pelo APL, entre eles a melhoria das condições de trabalho dos garimpeiros, alguns problemas ambientais e o fortalecimento do mercado da opala. Na penúltima seção, adota-se uma posição mais propositiva e são sugeridas algumas iniciativas de políticas públicas econômicas, ambientais, minerais e tecnológicas que poderiam contribuir para um aprimoramento tanto do APL de Pedro II, quanto de outros APLs minerais no país. A última seção resume e consolida as principais conclusões do estudo.

\section{Inovação e meio ambiente no contexto dos APLS e das PMEs}

O objetivo deste artigo é debater de que forma pode-se trabalhar o conceito de APLs para que tais arranjos não apenas estimulem o desenvolvimento econômico local e a inovação tecnológica, mas também fortaleçam grupos sociais mais vulneráveis e garantam a proteção ao meio ambiente. Ao trazer esse debate para a questão das pequenas minerações, há a expectativa de se definir estratégias para que os APLs não apenas aumentem a renda dos trabalhadores, mas também auxiliem pequenas mineradoras a sair do estágio atual, onde impera a informalidade, e criem ciclos virtuosos onde as atividades passem a ser realizadas formalmente, pagando impostos, garantindo boas condições de saúde e segurança dos trabalhadores e seguindo a legislação ambiental.

Para o desenvolvimento deste estudo, entende-se por APL as aglomerações territoriais de agentes econômicos, políticos e sociais - com foco em um conjunto específico de atividades econômicas - que apresentam vínculos, mesmo que incipientes. Assim, o estudo de um APL deverá incluir atores internos e externos à atividade produtiva, de forma a permitir uma compreensão econômica, social e política do setor estudado (IPIRANGA et. al, 2007).

De forma geral, APLs podem ser identificados pela presença de alguns elementos comuns, tais como um ambiente onde haja uma interação contínua e repetida entre os atores, uma pluralidade de redes formais e informais de relação, a valorização social do ato de empreender e o sentimento de pertencimento ao arranjo (IPIRANGA, 2008). Desse modo, o APL apresenta-se como um modelo conceitual interessante para estudar atividades mineradoras; em particular, aquelas de pequena escala.

Não é incomum que uma região mineradora se desenvolva naturalmente como um arranjo produtivo ao longo do tempo, pois como o principal fator de produção, a matéria prima, possui baixa mobilidade, os atores econômicos acabam por se concentrar em seu entorno. Em outras palavras, o minério atrai os garimpeiros e as empresas mineradoras, que atraem organizações de treinamento, sindicatos, firmas de manutenção de máquinas, joalheiros e negociantes. Esses atores interagem para explorar, comercializar e agregar valor aos minérios.

Existe uma ampla literatura sobre APLs, que não se restringe à descrição dos arranjos, mas também prescreve políticas e ferramentas que favorecem a sua criação e desenvolvimento (ALTEMBURG; MEYERSTAMMER, 1999; SCHMITZ, 1995; SCHMITZ; NADVI, 1999). Entretanto, muitos desses estudos focam a função dos APLs em obter ganhos de produtividade, acessar novas tecnologias e aumentar a escala de produção; ou seja, focam o aumento da competitividade das empresas e o desenvolvimento econômico de uma região (SILVA; DEMAJOROVIC, 2008)

Esse foco do estudo dos APLs é justificado pela grande necessidade de se estimular a inovação tecnológica entre as PMEs; uma vez que essas empresas enfrentam dificuldades de financiamento, de qualificação de mão de obra e de acesso a novas tecnologias (IPIRANGA et. Al, 2007). Como resultado desse cenário, no Brasil, somente $3,2 \%$ das empresas com menos de 50 empregados e apenas $2,1 \%$ daquelas na faixa entre 50 e 99 empregados desenvolvem produtos novos para o mercado nacional. A título de comparação, esse índice sobe para 33,4\% quando se trata de empresas com mais de 500 empregados (IBGE, 2005). O processo de inovação tecnológica pode ser caracterizado como uma ação cooperada de vários atores relacionados direta ou indiretamente a um sistema produtivo; por esse motivo, ela tende a ser beneficiada pela difusão da informação e conhecimento criada pelos APLs (IPIRANGA, 2008). 
Existe uma potencial relação entre inovação tecnológica e a melhoria do desempenho ambiental. Apesar de ser uma vertente importante, ela ainda parece não ocorrer naturalmente no contexto das PMEs. Na literatura sobre inovação ambiental, existem os autores que argumentam que novas tecnologias seriam capazes de reduzir impactos ambientais e, ao mesmo tempo, de aumentar a competitividade das empresas (MOL, 1996; NEALE, 1997; YOUNG, 2000). Essa argumentação tem por base principal o pressuposto de que novas soluções tecnológicas estariam voltadas principalmente para o aumento da eficiência dos processos produtivos, que não apenas seria um objetivo econômico, mas também ambiental. Outra possível contribuição da inovação tecnológica seria o desenvolvimento de processos produtivos que evitassem os impactos ambientais criados pelas atividades atuais. Segundo esse ponto de vista, prevenir a poluição valeria a pena, pois evitaria gastos relacionados à correção de tais impactos (COHEN, 1997; RINKEVICIUS, 2000).

Entretanto, a adoção de novas tecnologias ambientais não parece ocorrer naturalmente; ao menos, no caso das PMEs brasileiras. Tais empresas não possuem capacidade financeira suficiente para investir em soluções preventivas e tendem a focar ações corretivas que, em muitos casos, apenas aumentam os custos operacionais. Por exemplo, enquanto $34 \%$ das microempresas desenvolvem programas de reciclagem ou aproveitamento de resíduos, apenas $5 \%$ desenvolvem atividades para mudança na composição, desenho ou embalagem de produtos para torná-los menos danosos ao meio ambiente (BNDES et al, 1998). Por esse motivo, contar apenas com a influência indireta da inovação para melhoria do desempenho ambiental não parece ser uma estratégia eficaz, o que sugere a necessidade de iniciativas específicas.

Nesse caso, APLs também podem ser apresentados como instrumentos de promoção entre as PMEs de questões ligadas à saúde e segurança dos trabalhadores, bem como aos problemas ambientais. Ao se agregar tais temas no debate sobre APLs deve se considerar que esses arranjos têm bases técnicas e sociais bastante concretas nos locais onde se constituem e, portanto, são intrinsecamente associados aos seus territórios (GOULART, 2006). Dessa forma, como unidade de análise, o APL parece ser mais apropriado para o estudo do desenvolvimento local do que outras unidades de análise de organização industrial, como firmas, setor ou cadeias. Apesar de tais vantagens, poucos têm sido os estudos sobre APLs que analisam como essas configurações produtivas disseminam práticas ligadas às questões socioambientais (SILVA; DEMAJOROVIC, 2008).

Para contribuir com essa área de conhecimento, este artigo se propõe a estudar como políticas públicas para melhoramento de APLs poderiam envolver iniciativas para conectar as PMEs a cadeias que valorizem as questões socioambientais, além de ajudá-las a adaptar seu processo produtivo. Para tanto, parte-se do princípio de que muitas das características dos APLs podem ser aplicadas à área socioambiental, entre elas:

- escala de organização de movimentos sociais e legais;

- economias de escala para encontrar soluções coletivas;

- desenvolvimento e disponibilidade de habilidades especializadas;

- potencial para gerar inovação tecnológica, decorrente da difusão da informação e do aprendizado.

No entanto, além desses aspectos positivos - devido à complexidade surgida da interação de diversos atores -, um APL pode também apresentar uma série de limitações para alavancar melhoramento socioambiental, tais como:

- dificuldade para encontrar soluções devido ao grande número de atores;

- alto valor dos custos ou investimentos devido à grande escala;

- alto risco de um impacto negativo no APL, o que pode inviabilizá-lo economicamente;

- resistência política ou cumplicidade para barrar as mudanças (como no caso do cumprimento da lei);

- maior oportunidade para o "pacto com o diabo";

Essas oportunidades e desafios necessitam de maior estudo, de maneira a indicar quais seriam as melhores alternativas. Neste artigo abordaremos a aplicação desses conceitos ao caso do APL de opalas em Pedro II. 


\section{O garimpo de gemas no Brasil}

\section{Aspectos gerais}

Não existem dados atuais sobre a situação dos garimpos no Brasil. Em 1993, o Departamento Nacional de Prospecção Mineral (DNPM) realizou o Levantamento Nacional de Garimpeiros e estimou um total de 400.000 garimpeiros e 2.000 garimpos espalhados pelo país. Os garimpos empregam, principalmente, mão de obra não qualificada e oriunda do meio rural, uma vez que mais da metade dos entrevistados pelo DNPM tinham como atividade anterior o próprio garimpo ou atividade agrícola. Além disso, $51 \%$ dos entrevistados $(59,9 \%$ na região nordeste) ainda desenvolviam atividades agrícolas de forma complementar ao garimpo (MIRANDA et al, 1997). A forma de contratação dos garimpeiros é quase sempre informal e, na maioria das vezes, os contratos são verbais (BARRETO, 2001).

Como forma de organizar a atividade garimpeira, em 1989 foi aprovada a Lei $\mathrm{n}^{\mathrm{0}} 7.805$ (BRASIL, 1989). Segundo essa lei, a Permissão de Lavra Garimpeira (PLG) permite que algumas jazidas (dependendo de critérios fixados pelo DNPM) possam ser lavradas independentemente de trabalhos prévios de pesquisa. Embora a outorga da PLG ainda dependa de prévio licenciamento ambiental, em teoria, ela seria menos burocrática que a portaria de lavra normalmente concedida a empresas. A lei estabelece ainda, que trabalhos em área de garimpagem sejam realizados de forma associativa, com prioridade para cooperativas. Segundo o texto da lei, existe um limite de 50ha para áreas de garimpagem, salvo no caso de cooperativas. Nessa situação, a Portaria n⿳0 29 do DNPM define um limite máximo de 10.000ha para a Amazônia Legal e de 1.000ha para as demais regiões (DNPM, 2007a).

Ter como principal objetivo o estímulo às cooperativas de garimpeiros, (especialmente no caso de gemas) é consequiência da alta informalidade do setor, que é resultado de fatores diversos. Em primeiro lugar, esses minerais podem ser extraídos e beneficiados sem a necessidade de muita tecnologia ou mão de obra qualificada. Em segundo lugar, o investimento na extração de gemas caracteriza-se por ser de alto risco, o que desestimula o envolvimento de empresas formais. Por fim, existe uma limitada capacidade institucional (falta de pessoal e de infra-estrutura) das agências governamentais para fiscalização. Entretanto a formação de cooperativas de garimpeiros, freqüentemente, é apenas uma ação jurídica e legal, pois em muitos casos não são seguidos os procedimentos e princípios cooperativos (TEIXEIRA; LIMA, 2004).

Além da informalidade, outro problema que caracteriza o garimpo e as pequenas minas é a baixa capacidade tecnológica. Muitas vezes, essas operações são realizadas por indivíduos sem acesso a equipamentos, e o desenvolvimento tecnológico tradicionalmente ocorre de forma muito lenta (MACEDO et al, 2003). Segundo Barreto (2001), isso se deve, em parte, à legislação aplicada até 1988, pois esta considerava atividade garimpeira apenas aquela desenvolvida por meio de práticas rudimentares. Qualquer inovação era vista como uma ameaça de descaracterização do garimpo que levaria à perda dos incentivos existentes.

Outra característica dos garimpos e pequenas minas de gemas e minerais não-metálicos são os impactos ambientais, que são bastante diferentes daqueles produzidos pela grande mineração de minerais metálicos. A mineração artesanal de gemas não utiliza produtos químicos e, normalmente, ocorre em pequena escala. Em princípio, isso tornaria o controle e a mitigação de impactos ambientais mais simples, mas, por esse mesmo motivo, muitas vezes, as atividades de pequena mineração não são consideradas prioridade pelos órgãos ambientais. Entretanto, como existe uma grande quantidade de pequenos empreendimentos, o impacto total torna-se significativo e ocorre de forma bastante extensiva. Entre esses impactos, os mais comuns são o desmatamento e a alteração do curso de corpos d'água para acesso às jazidas, o assoreamento de rios e a redução da qualidade da água. Além disso, há uma degradação geral da paisagem, devido à produção de buracos, cavas e túneis. Apesar de serem problemas de fácil solução do ponto de vista técnico, historicamente, as empresas e cooperativas de garimpo não têm adotado ações preventivas ou corretivas para resolvê-los (MACEDO et al, 2003).

Além dos impactos ambientais descritos anteriormente, o surgimento de garimpos também tem impactos sociais importantes, uma vez que a descoberta de jazidas minerais facilmente acessíveis pode atrair garimpeiros 
de diferentes regiões. Quando isso ocorre próximo a pequenas cidades, ondas migratórias aumentam a pressão sobre a infra-estrutura e serviços urbanos (em especial moradia, sistema de saúde e saneamento). Caso a atividade produza altos rendimentos, ela pode também intensificar outros problemas, como violência, o uso de álcool e drogas e a prostituição (MIRANDA et al, 1997).

Tanto a informalidade, quanto a lenta inovação tecnológica e a falta de controle ambiental podem ser associadas à limitada capacidade institucional dos órgãos governamentais. Essa questão foi intensificada a partir do início dos anos 1990, quando houve um esvaziamento dos órgãos ligados às atividades de mineração e agências federais e estaduais de meio ambiente. Como decorrência desse processo, muitos funcionários experientes e bem treinados foram dispensados ou realocados em outras atividades, o que reduziu ainda mais a capacidade técnica e institucional desses órgãos (MACEDO et al, 2003).

Assim como na extração, a informalidade e os pequenos empreendimentos também caracterizam o beneficiamento e comércio de gemas. As empresas com menos de 20 empregados correspondem a $73 \%$ do total, enquanto as empresas de pequeno porte (entre 20 e 99 empregados) representam 23\%. Apesar da alta informalidade do setor diminuir o nível de precisão das estatísticas (acredita-se que 50\% das empresas do setor não sejam formalizadas), há estimativas de que existam cerca de 850 empresas de lapidação ou obras de pedra no país (IBGM, 2006).

\section{Particularidades da região Nordeste e do estado do Piauí}

Se no Brasil, as condições da pequena mineração e do garimpo são problemáticas, tornam-se ainda mais críticas no nordeste do país. Nessa região, o garimpo quase sempre é manual e apenas $40 \%$ das pequenas mineradoras formais utilizam equipamentos pesados (retroescavadeiras, caminhões etc.). Em algumas minas, existem bombas d'água e exaustores, mas em muitos casos não há disponibilidade de energia elétrica nas proximidades das minas, o que as obriga a utilizar motores movidos a óleo, aumentando os custos de produção e de manutenção.

Entre as atividades minerais informais mais comuns no Nordeste está a cata de pedras semipreciosas. Tal atividade é, na maioria das vezes, feita na época da seca, como estratégia de complementação de renda por agricultores. "Essa complementaridade entre a mineração e a agricultura tem contribuído para manter o frágil equilíbrio da economia nas áreas onde ocorrem jazidas [...]" (SICSÚ; LIMA, 1991, p.10). Por esse motivo, o garimpo e a pequena mineração envolvem, de forma extensiva, um número significativo de pessoas na região.

Entretanto, o envolvimento de um elevado número de pessoas com o garimpo no Nordeste parece decorrer da falta de opções, uma vez que a remuneração dos garimpeiros é muito baixa na região. Segundo dados do Levantamento Nacional de Garimpeiros, em 1993, a remuneração média nacional para os garimpeiros (considerando 60 horas de trabalho semanais) era de aproximadamente 3,8 salários mínimos (equivalente a 19,2g de ouro), enquanto a média nordestina era de 1,8 salário mínimo (9,1g de ouro). Apesar dessa baixa remuneração, era no Piauí que os garimpeiros permaneciam no garimpo por períodos mais longos: a média estadual é de 13 anos, enquanto no país, os garimpeiros costumam passar menos de quatro anos (MIRANDA et al, 1997).

Atualmente, a mineração de gemas no Piauí (assim como o setor mineral de forma geral) enfrenta alguns obstáculos para seu desenvolvimento. Entre estes, destacam-se a falta de uma política setorial que inclua mapeamento geológico e laboratórios de análise mineral, a precariedade da infra-estrutura básica (rodovias, energia elétrica, comunicação etc.) e limitações institucionais dos órgãos públicos, como duplicidade de funções, demora para o licenciamento, excesso de taxas e o desconhecimento da legislação pelos técnicos do governo (FUNDAÇÃO CEPRO, 2005). 


\section{Opalas em Pedro II}

\section{A opala}

Apesar de ser comercializada como gema, a opala não é uma rocha cristalizada, mas, sim, uma forma amorfa de aspecto vitroso ou resinoso, constituída de sílica e água, além de algumas impurezas, como cálcio, magnésio, óxido de alumínio e óxido de ferro (SOUZA, 1985). O uso da opala em jóias foi iniciado em 400 a.C e seu valor depende do tamanho, da cor e de seu jogo de cores. Elas podem ser usadas tanto na confecção de jóias, quanto de peças de artesanato.

As opalas, geralmente, ocorrem em terrenos áridos e profundidades médias (entre 15 e 40m). Até meados da década de 1930, o principal produtor era a República Tcheca, mas, no dias de hoje, $90 \%$ da produção é originária da Austrália, embora a opala também seja encontrada no Brasil, no México, nos EUA e em Honduras (OLIVEIRA, 1998; OLIVEIRA; CARDOSO, 1979). No Brasil, já foram encontradas opalas em Minas Gerais, Bahia, Mato Grosso, Rio Grande do Sul, Paraná, São Paulo e Ceará. Entre essas ocorrências, as jazidas mais importantes localizam-se no Piauí, nos municípios de Pedro II e Buriti dos Montes (FUNDAÇÃO CEPRO, 2005; OLIVEIRA; CARDOSO, 1979). Com relação à comercialização, os principais mercados de opala bruta e lapidada são Pedro II, Teresina, Parnaíba e Buriti dos Montes (OLIVEIRA, 1998). No município de Buriti dos Montes, há perspectivas de exploração comercial da opala, mas o mineral dessa região é mais transparente e possui menos jogo de cores do que aquele encontrado em Pedro II, recebendo menor atenção de garimpeiros e comerciantes. As jazidas mais importantes estão em Pedro II, numa área de $200 \mathrm{~km}^{2}$ ao redor da sede do município (FUNDAÇÃO CEPRO, 2005; OLIVEIRA; CARDOSO, 1979).

\section{Pedro II}

Pedro II localiza-se no noroeste do estado do Piauí, a cerca de 200km de Teresina. A sede do município está a aproximadamente $600 \mathrm{~m}$ acima do nível do mar, sobre a Serra dos Matões. Como a cidade está em uma região semi-árida, seu clima é seco, com temperaturas amenas devido à altitude. Os principais rios da região (Matos, Correntes, Parafuso e Capivara) são intermitentes, fazendo parte das bacias dos rios Poti e Longá.

Pedro II é uma cidade de pequeno porte com tradição agrícola. Em 2000, havia 36,2 mil habitantes, dos quais mais de $42 \%$ moravam na área rural; percentual superior às médias do estado do Piauí $(37,1 \%)$ e do Brasil (18,8\%). A infra-estrutura do município é bastante precária, principalmente, quanto ao saneamento básico: o sistema de abastecimento de água atende pouco mais de $20 \%$ dos domicílios - muito abaixo da média estadual - e, além disso, não há sistema de tratamento de esgoto na área urbana (PNUD, 2003).

A situação social em Pedro II é bastante preocupante, pois a renda per capita do município em 2000 era equivalente à metade da média estadual e a um quinto da média nacional. Além disso, três quartos da população viviam com metade de um salário mínimo. O Índice de Desenvolvimento Humano (IDH) do município está abaixo da média nacional; o município ocupa a $4.560^{a}$ posição no país e a $74^{a}$ posição no Piauí (PNUD, 2003). Segundo relatos de técnicos da prefeitura, entre 2004 e 2007, o número de famílias cadastradas no programa Bolsa Família passou de 1.800 para 7.000.

A economia de Pedro II é tradicionalmente vinculada à agricultura e à pecuária, que, no entanto, são atividades muito vulneráveis, devido ao clima semi-árido. Os recursos de água subterrânea são limitadíssimos e as chuvas inconstantes (OLIVEIRA; CARDOSO, 1979). Por exemplo, em 2005, a estiagem causou perda de $85 \%$ da lavoura de arroz, $56 \%$ da de feijão, $75 \%$ da de milho e $48 \%$ da produção de mandioca, levando a prefeitura a decretar estado de emergência (BATISTA, 2005).

Como atividades complementares existem o turismo regional (Pedro II é a "Suíça Piauiense", pelo seu clima mais ameno) e o artesanato. Em 2005, foi criada a Associação de Artesãos de Pedro II, com apoio do Sebrae. Essa associação trabalha, principalmente, com tecelagem e bordado de redes, toalhas de mesa e outros utensílios (JANSEN, 2005). 
A importância da mineração e do beneficiamento da opala na economia local tem sido bastante oscilante desde a década de 1940. Atualmente, há ações conjuntas de instituições municipais, estaduais, federais e privadas para a consolidação de um APL ligado à opala. Essas iniciativas visam tanto à retomada da extração da opala, quanto ao desenvolvimento do artesanato e do turismo ligados à atividade mineral.

\section{Breve histórico da opala em Pedro II}

A descoberta da opala em Pedro II está registrada apenas na história oral dos garimpeiros e, dessa forma, vai se transformando e ganhando novos contornos ao longo do tempo. A primeira pedra foi encontrada entre o final da década de 1930 e o início da de 1940 e é associada a casos fortuitos. Algumas versões afirmam que o primeiro a encontrar a pedra foi um agricultor que estava preparando o solo para a roça, e que ao arrancar um pé de macaxeira, deu com a pedra brilhante. Outras versões referem-se a um caçador que enfiou a mão na toca de um tatu-peba e lá encontrou uma gema. Também há referências a um morador de Pedro II que usava botões feitos de opala para enfeitar suas roupas, chamando a atenção do resto da população (OLIVEIRA, 1998; SOUZA, 1985).

A identificação das pedras como opala foi feita graças à intervenção de um chefe político da época. Um agricultor teria levado algumas amostras para ele, que numa ida a Teresina, mostrou-as a engenheiros e técnicos que as identificaram. Pedras semelhantes, encontradas no local conhecido como "Centro", foram também identificadas como opala por um professor na cidade (OPALAS NORDESTE, 2007). A partir da identificação das rochas como opala, começaram a surgir as primeiras áreas de garimpo e mineração. Algumas foram encontradas em um local chamado de Crispim, onde foi aberta a mina do "Boi Morto", que se tornou a principal jazida da região. Além da Boi Morto, outras jazidas foram descobertas em "Bom Lugar" e na "Roça".

Durante a década de 1950, a garimpagem era feita em pequenas galerias, em condições precárias, não sendo incomum ocorrem desabamentos e morte de garimpeiros (OLIVEIRA; CARDOSO, 1979). As pedras eram vendidas em estado bruto a artesãos da região Sudeste que vinham até Pedro II. Além disso, alguns garimpeiros faziam viagens esporádicas até o Rio de Janeiro para tentar vendas mais rentáveis.

Em meados da década de 1960, a Empresa de Minérios Brasil Norte-Nordeste (Emibra) passou a explorar a área da Boi Morto. Os relatórios de pesquisa indicavam reservas inferidas de aproximadamente $30.000 \mathrm{~kg}$ de opala, em uma área de 355 ha. A comercialização nesse período era informal e não existem dados confiáveis. $\mathrm{O}$ Anuário Mineral Brasileiro de 1978 não dispõe de dados de produção e menciona exportações que variavam entre $1 \mathrm{~kg}$ e $6 \mathrm{~kg}$ (OLIVEIRA; CARDOSO, 1979). A época de maior produção foi quando a Emibra operou a mina de Boi Morto e chegou a contar, entre os anos de 1960 e de 1976, com mais de 80 funcionários.

Outra mina importante em Pedro II, conhecida como mina do "Mundote", localiza-se na área da "Roça", a cerca de $10 \mathrm{~km}$ da sede do município. Adquirida em 1972, essa área possuía uma reserva inferida de $35.000 \mathrm{~kg}$ (OLIVEIRA; CARDOSO, 1979). Nesse local foi encontrada uma opala de 4,75kg, em 1975, então, vendida para o Museu de História Natural de Londres.

Durante o "período áureo" da opala, chegou a haver cerca de 30 jazimentos ocupados em diferentes ocasiões. Enquanto as empresas se voltaram para os depósitos maiores, os primários, os depósitos secundários foram explorados, principalmente, por garimpeiros. Esses depósitos se formam especialmente nos leitos dos rios. Contudo, apesar do acesso aos rios ser mais fácil, muitas vezes, em alguns locais, os garimpeiros se viam obrigados a retirar água ou, mesmo, a mudar o curso do rio para poder chegar às jazidas, o que causou significativo impacto ambiental na região (OLIVEIRA; CARDOSO, 1979).

Os garimpeiros sempre foram bastante vulneráveis como grupo social, , particularmente, devido às dívidas que contraem para se manter no negócio. Em 1970, eles constituíram sua primeira associação. Segundo dados da Delegacia Regional do Sindicado Nacional de Garimpeiros já houve mais de 3.000 garimpeiros cadastrados em Pedro II (JANSEN, 2007). Apesar disso, nunca houve uma "corrida da opala" no município. De acordo com os garimpeiros, os garimpos de opala são tranqüilos e raramente há conflitos ou brigas. Em parte, isso se deve à dificuldade de se encontrar boas opalas, característica que mantém afastados garimpeiros mais "aventureiros". 
De forma geral, a maior parte dos garimpeiros de Pedro II são pessoas da localidade, que dividem seu tempo entre as roças, durante a época da chuva, e o garimpo, no período de estiagem.

Graças à proliferação de minas e garimpos durante esse período, uma grande quantidade de opala foi extraída e exportada, mas sem uma participação significativa do poder público. Alguns moradores de Pedro II falam em pedras escondidas em santos de pau oco, em aviões e helicópteros (que na época muitos pensaram ser espaçonaves extraterrestres) pousando em Pedro II e, mesmo, em pedras confiscadas pela polícia federal, que, posteriormente, voltavam ao mercado. Por esses motivos, os dados de produção são pouco confiáveis. Uma das poucas iniciativas governamentais foi o Projeto Opala em Pedro II, realizado pela Companhia de Pesquisa de Recursos Minerais (CPRM), realizado no final da década de 1970. Através desse projeto foi feito um mapeamento geológico detalhado da região, estudadas ocorrências e analisadas as mineralizações e sua gênese (OLIVEIRA; SOARES FILHO, 1983).

A partir de meados da década de 1980, começou a haver um esvaziamento de Pedro II; ao menos, com relação às empresas. Oliveira e Soares Filho (1983) estiveram na região e contabilizaram 22 garimpos abandonados, três paralisados e apenas três ativos. Segundo os autores, existiam cerca de 200 garimpeiros na região, mas apenas uns 30 tinham o garimpo como atividade exclusiva. Desde a metade dos anos 1980, a maior parte das opalas foi retirada em atividades de garimpagem (SOUZA, 1985), sendo vendida de forma irregular ainda em estado bruto para turistas que visitavam a cidade. Ao longo desse período, a Delegacia da Receita Federal em Pedro II ficou desativada (OLIVEIRA, 1998).

A causa desse movimento pode ser associada a uma maior dificuldade de se encontrar pedras de qualidade e a uma redução da lucratividade. Entretanto, não é claro se isso ocorreu devido ao esgotamento natural das reservas ou à exploração inadequada desses recursos. Estudos estimaram uma reserva geológica de 1.200t de opala bruta em Pedro II (OLIVEIRA, 1998). Além disso, muitos garimpeiros afirmam que nem 5\% das reservas de opala foram exploradas. No entanto, como não se sabe ao certo o quanto já foi explorado, fica difícil estimar o quanto ainda existe no subsolo de Pedro II.

Um importante fator na redução da atividade de mineração foi o fechamento da Emibra. Com a morte do seu proprietário, uma série de disputas pela empresa, juntamente com a crescente raridade das pedras, acabou dificultando o funcionamento da mina de Boi Morto. Em 1988, a empresa foi oficialmente fechada e a mina, ocupada informalmente por garimpeiros que hora trabalhavam os rejeitos da empresa, hora tentavam a sorte em algumas galerias. Entretanto, as atividades eram desenvolvidas sem supervisão, não sendo raros os deslizamentos, como o que matou três garimpeiros em 1989.

\section{Revitalização da extração de opalas}

A partir do final da década de 1980, iniciaram-se alguns movimentos de instituições públicas e privadas para tentar fortalecer a cadeia da opala em Pedro II. A principal estratégia, nessa época, foi o treinamento e a formação de ourives e joalheiros, agregando valor e aumentando a parte da renda que fica na cidade. Em 1988, a Companhia de Desenvolvimento do Piauí (Comdepi), com financiamento da Superintendência de Desenvolvimento do Nordeste (Sudene), ofereceu cursos de lapidação de opalas. Para tanto, trouxe instrutores da cidade de Parnaíba, pois Pedro II ainda não dispunha de mão-de-obra qualificada (PINTO; FEITOSA, 2007). Essa iniciativa chegou a originar uma escola de artesanato mineral, posteriormente, transferida para Parnaíba, por ser esta cidade o principal centro turístico do estado (OLIVEIRA, 1998). Mesmo assim, os cursos renderam frutos e possibilitaram a criação de algumas oficinas e lojas de jóias na cidade. Com a transferência da escola da Comdepi, alguns joalheiros chegaram a ir buscar ourives em Pirinópolis (GO) para trabalharem e treinarem a mão-de-obra de Pedro II. À medida que se formava um mercado local para a venda de pedras lapidadas e de jóias, alguns garimpeiros, em busca de maior estabilidade, foram mudando de atividade, abrindo então suas próprias oficinas e lojas.

No início dos anos 2000, houve uma retomada das atividades de garimpo em Pedro II, em decorrência, principalmente, do interesse de uma empresa pela mina de Boi Morto. A princípio, criou-se uma situação de disputa entre a empresa e os garimpeiros que trabalhavam na área da mina. Essa disputa criou uma situação bastante desconfortável na cidade, pois, de um lado, havia a empresa (pertencente a um estrangeiro) - que tinha 
o direito legal à propriedade - e, do outro, um grupo de moradores locais que garimpavam para garantir sua subsistência.

Em 2003, esse conflito chamou a atenção da mídia regional e das agências governamentais (Ibama, Semar, Ministério Público do Trabalho e DNPM). Uma vez no local, as agências optaram por interditar tanto a área da mina de Boi Morto, quanto os demais garimpos, já que todos estavam em situação irregular.

Com o passar do tempo, a situação foi se tornando insustentável, pois os garimpeiros não tinham condições de trabalhar na formalidade e o licenciamento ambiental da empresa esbarrava no passivo criado pelos resíduos deixados pela Emibra (CETEM, 2005). Essa situação de impasse levou a uma negociação entre as partes, resultando na doação do monte de rejeito (montoeira) deixado pela Emibra aos garimpeiros. A solução era interessante para a empresa, pois a montoeira deixava de ser um passivo ambiental para tornar-se responsabilidade dos garimpeiros. Essa alternativa, porém, somente foi possível após longa negociação e mediação de técnicos de órgãos estaduais e federais. O resultado dessa mobilização foi a criação do projeto APL em 2005, financiado pela Financiadora de Estudos e Projetos (Finep), tendo por conveniente a Fundação de Desenvolvimento e Apoio à Pesquisa, Ensino e Extensão (Fundape-PI) e como interveniente, o Sebrae do Piauí.

O diagnóstico elaborado para a realização do projeto identificou que a cadeia produtiva da opala apresentava, em todas as etapas, um baixo nível de eficiência tecnológica e econômica. Do ponto de vista tecnológico, essa situação gerava condições inadequadas de trabalho, problemas ambientais e produtos de baixo valor agregado. Quanto ao aspecto econômico, havia evasão de divisas e gestão inadequada dos negócios. Como causas dessa ineficiência, foram apontadas a informalidade tradicional do setor e a qualificação insuficiente das pessoas envolvidas nas diversas atividades da exploração e beneficiamento da opala (HENRIQUES; SOARES, 2005). Diversas atividades foram propostas para tentar minimizar os problemas identificados e, assim, aumentar a produtividade e consolidar a cadeia produtiva da opala (DUARTE, 2006; HENRIQUES; SOARES, 2005). Essas propostas foram organizadas em quatro grandes grupos (FINEP, 2005):

- formalização das atividades ligadas à extração de opala: cadastro das frentes de lavra, regularização trabalhista, ambiental, fundiária e mineral das áreas de extração;

- melhoria das condições de trabalho e redução dos impactos ambientais da lavra: diagnóstico da situação, treinamento de garimpeiros sobre questões de segurança e meio ambiente, desenvolvimento de novas técnicas de lavra e de beneficiamento, elaboração de tecnologias para aproveitamento de resíduos e a implantação de plano de recuperação das áreas degradadas;

- agregação de valor no beneficiamento da opala: treinamento em design de jóias, lapidação e joalheria, incluindo questões de saúde do trabalhador e meio ambiente, apoio na participação de eventos e exposições; e

- fortalecimento gerencial e comercial da cadeia da opala: apoio à formação de associações e cooperativas, treinamento em gestão empresarial, criação de marca, negociação de linhas de crédito específicas junto a agentes financeiros, elaboração de projeto de turismo mineral.

Embora nem todas as ações propostas tenham sido implementadas (ou atingido os resultados esperados), elas tiveram efeitos positivos sobre a dinâmica econômica de Pedro II. O processo de legalização da situação trabalhista dos garimpeiros iniciou-se antes da criação do APL. O Sebrae já vinha atuando na região e ajudou os garimpeiros a formarem uma associação em 2001, para tentar formalizar sua situação e garantir o acesso às jazidas. Entretanto, somente após o início do processo de legalização, os garimpeiros foram orientados pelo DNPM no sentido de que deveriam formar uma cooperativa para melhor se adequarem à legislação. Assim, a associação foi desfeita e a Cooperativa dos Garimpeiros de Pedro II foi fundada em 2004.

Não há dados precisos sobre o número total de garimpeiros atuando na região de Pedro II. Algumas estimativas falam em um total de 700, dos quais 300 atuariam exclusivamente no garimpo,enquanto o restante teria o garimpo como fonte complementar de renda (GARIMPEIROS, 2005). A cooperativa conta com cerca de 70 membros, dos quais aproximadamente 60 estão ativos em diferentes frentes de trabalho. Para fazer parte da 
cooperativa, os membros precisam participar de um curso de cooperativismo, bem como adquirir a cota-parte da cooperativa no valor de $\mathrm{R} \$ 400,00$ (COOGP, 2004). Além dessa contribuição, os cooperados pagam à cooperativa entre $10 \%$ e $20 \%$ do seu rendimento como contribuição para a sua manutenção.

Apesar da tentativa de legalizar a situação trabalhista por meio da cooperativa, os garimpeiros ainda enfrentam alguns desafios. Um deles é o não pagamento das contribuições para o Instituto Nacional de Seguro Social (INSS). Isso se deve, principalmente, à pequena arrecadação que os trabalhadores têm obtido com o garimpo. Isso gera uma situação de grande vulnerabilidade, uma vez que, dessa forma, eles não possuem perspectiva de aposentadoria, nem de cobertura em caso de acidente ou doença.

Com relação ao regime de trabalho, uma das principais contribuições do APL foi organizar o espaço onde a atividade é desenvolvida, melhorando aspectos relativos à segurança (principalmente, devido ao acompanhamento sistemático de um engenheiro de minas) e à ergonomia e conforto dos trabalhadores.

Apesar dessas melhorias, não houve ainda uma melhoria significativa na produtividade dos garimpos. Segundo informações dos garimpeiros, o grama de opala "extra" (aquela de melhor qualidade) pode valer entre $\mathrm{R} \$ 100,00$ e $\mathrm{R} \$ 300,00$, mas essas são cada vez mais difíceis de encontrar. Os garimpeiros da cooperativa vivem efetivamente da comercialização do xibiu (pequenos fragmentos de baixo valor), cujo lote de $20 \mathrm{ml}$ (medidos em caixas de filme fotográfico) é vendido a $\mathrm{R} \$ 80,00$. A não ser no caso esporádico de encontrar uma pedra de maior valor, esse é o rendimento de uma semana de trabalho, o que significa uma renda mensal de cerca de $\mathrm{R} \$ 320,00$ por mês.

Apesar do trabalho no garimpo estar relativamente bem organizado, as condições de trabalho ainda são precárias. Os fatores que parecem mais penalizar os trabalhadores são: a exposição constante ao sol e ao calor, a poeira e o esforço físico durante a escavação e o transporte. Apesar de ter sido feito um barracão para os garimpeiros descansarem nos intervalos, fazerem suas refeições e deixarem seus pertences, esse ainda precisa passar por melhorias.

Se as condições de trabalho ainda não são ideais no garimpo, maiores avanços foram obtidos quanto às questões de legalização ambiental e mineral. Tradicionalmente, os garimpeiros sempre trabalharam na informalidade, sem licença ambiental e sem alvará de lavra. Para terem acesso às jazidas, realizavam acertos com os proprietários superficiários, que recebiam entre $15 \%$ e $20 \%$ da sua receita total. O sistema funcionou razoavelmente bem por mais de 40 anos, uma vez que o controle dos órgãos ambientais e minerais sempre foi muito frágil. Um dos desafios enfrentados pelo projeto APL é exatamente mudar essa cultura da informalidade.

Do ponto de vista dos garimpeiros, os custos envolvidos para o licenciamento ambiental sempre foram um dos maiores empecilhos para a legalização. Esses custos envolviam as taxas para obtenção das licenças, os gastos com a elaboração dos estudos ambientais e minerais e a remuneração de técnicos para o acompanhamento dos trabalhos de extração.

Embora o APL não tenha viabilizado o licenciamento gratuito (e não tenha essa proposta), ele disponibilizou, através de uma bolsa do Conselho Nacional de Desenvolvimento Científico e Tecnológico (CNPq), um engenheiro de minas para assessorar a cooperativa na obtenção das licenças e no desenvolvimento de suas atividades no garimpo.

A preocupação de obter o licenciamento beneficiou, indiretamente, os órgãos ambientais, uma vez que só a partir das experiências do APL de Pedro II, os técnicos dos órgãos ambientais estadual e federal passaram a conhecer de verdade o processo de licenciamento de atividades de mineração. Depois de definidos os procedimentos burocráticos, esses órgãos tornaram-se mais eficientes e, agora, as novas licenças são liberadas em menos de um ano. Essa maior agilidade também serviu para motivar outros garimpeiros a licenciarem suas atividades. Em 2007, além das três concessões de lavra cedidas para a mina de Boi Morto, havia sete concessões de lavra garimpeira ativas, quatro autorizações de pesquisa, três requerimentos de lavra garimpeira e um requerimento de pesquisa (DNPM, 2007b). Nesse sentido, existe a perspectiva, pela equipe do APL, de formar uma associação de proprietários de áreas com ocorrência de opala (atualmente, há 19 proprietários 
cadastrados), de forma que essa associação possa também contratar um engenheiro de minas e, assim, tornar o processo de obtenção de licença ainda mais ágil.

Em resumo, do ponto de vista dos garimpeiros, as principais vantagens da formação do APL foram alterações nas condições e rotinas de trabalho que, agora, são feitas com mais segurança e algum conforto. Do ponto de vista institucional, esses trabalhadores agora atuam de acordo com as normas ambientais, o que se transforma em benefício indireto para eles e a população de Pedro II. Os garimpos também passaram a funcionar de acordo com a legislação mineral, o que significa o fim do risco de expulsão das áreas de garimpo. Do ponto de vista da comercialização, a formação da cooperativa e do APL ainda não foram convertidos em aumento de produção, nem mesmo em maior poder de barganha diante de joalheiros e atravessadores.

Conforme mencionado anteriormente, durante muito tempo, as gemas de opala foram extraídas e comercializadas na forma bruta; muitas vezes, no mercado informal. As primeiras lojas datam do final da década de 1980 e nessa época comercializavam apenas pedras brutas e lapidadas. As jóias somente começaram a ser produzidas em Pedro II a partir do ano 2000. Segundo relato dos garimpeiros, é elevado o grau de organização dos joalheiros e lapidários. Parece ainda haver um reduzido número de compradores, uma vez que parte significativa da produção da cooperativa é adquirida por duas joalherias e três comerciantes de pedras (dois dos quais são o presidente e o vice-presidente da cooperativa).

Normalmente, o beneficiamento e o comércio de jóias são atividades correlacionadas. Quase toda loja está associada a uma pequena ou média oficina, e mesmo as oficinas "independentes" comercializam peças no varejo. As origens dos comerciantes de jóias em Pedro II são variadas. Há antigos garimpeiros (ou parentes de garimpeiros), há ourives e joalheiros que resolveram tentar também a venda direta e há, ainda, pessoas da cidade sem nenhuma relação anterior com a opala, mas que viram no mercado de gemas uma oportunidade de negócio. Um dos principais polarizadores dessas empresas é a Associação dos Joalheiros e Lapidários de Pedro II (Ajolp), que conta com quase 20 associados. A Ajolp foi fundada em 2004, e para fazer parte dela os interessados precisam participar de um curso de associativismo e contribuir com as taxas mensais de administração.

Como contrapartida, os associados têm acesso a diferentes benefícios. A associação tem forte vínculo com o Sebrae e com os órgãos que compõem o APL, obtendo junto a este cursos de capacitação para ourives e joalheiros, bem como apoio para participação em feiras e exposições. Por exemplo, através do APL, os joalheiros de Pedro II puderam participar do Fashion Business Week 2007, no Rio de Janeiro, e tiveram acesso a financiamento do Ministério do Desenvolvimento Agrário para produzir um catálogo de seus produtos. Outra colaboração do APL foi trazer um designer de Nova York para oferecer consultoria aos joalheiros de Pedro II (BATISTA, 2007). No caso dos eventos, quando as lojas não dispõem de recursos para expor individualmente, a Ajolp envia um representante coletivo, que leva mostruário e referência de diferentes lojas individuais. Aparentemente, apesar da Ajolp ter sido fundada no mesmo ano da cooperativa de garimpeiros, ela parece ter uma estrutura mais robusta e eficaz.

Entretanto, um dos desafios para a Ajolp ainda é convencer seus associados das vantagens de se formalizar. Existem apenas quatro empresas que deixaram o mercado informal, motivadas, principalmente, por oportunidades de exportar sua produção. Para as "empresas líderes", o mercado internacional representa entre $40 \%$ e $60 \%$ de suas vendas, sendo os principais destinos EUA e Europa. Considerando o mercado nacional, a maior parte de sua produção é vendida para revendedores fora de Pedro II.

Apesar das demais empresas não exportarem sua produção, elas parecem também conseguir ir além das "fronteiras de Pedro II". Apesar de manterem uma estrutura familiar e informal (HENRIQUES; SOARES, 2005; OLIVEIRA, 1998), muitas trabalham com revendedores ou comercializam diretamente com lojas em capitais do Nordeste ou do Sudeste. Dessa forma, não é claro o papel da venda varejista dentro da cidade. Aparentemente, ela pode funcionar como atrativo para o turismo (gerando externalidades positivas para esse outro setor) ou funcionar como chamariz para comerciantes de fora da cidade. 


\section{Análise e discussão do caso: oportunidades para melhorar o APL}

\section{Condições de trabalho no garimpo}

Um dos principais problemas identificados é a exposição dos trabalhadores ao sol e ao calor. Como existem alguns garimpeiros com idade avançada (superior a 60 anos), esse se torna um problema grave. A situação parece ainda mais preocupante devido à falta de água no garimpo. Para lidar com essa questão, poderiam ser desenvolvidos sistemas móveis de sombreamento (algo como guarda-sóis produzidos com folhas de carnaúba ou outro material disponível no local) para proteger, ao menos, os garimpeiros que trabalham em posições fixas, como na escavação, no peneiramento, na lavagem e na separação.

Um segundo problema refere-se à quantidade de material particulado ao qual os garimpeiros estão expostos. Depois que o material está seco, seu transporte, quebra e, especialmente, peneiramento coloca em suspensão grande quantidade de pequenas partículas. Como o solo onde as opalas se encontram é rico em sílica, é necessário levar em consideração o risco de desenvolvimento de silicose entre os garimpeiros. Alguns deles utilizam panos enrolados no rosto para proteger boca e nariz, mas isso é incômodo por causa do calor. Esse problema deveria ser enfocado pela equipe do APL, sendo feita uma conscientização dos trabalhadores sobre o problema e a distribuição de máscaras ou desenvolvimento de alguma tecnologia individual para minimizar o problema.

Outra questão relacionada às condições de trabalho, ao menos, no garimpo de Boi Morto, é a condição do barracão dos garimpeiros. Este barracão é feito de madeira e telhado de palha. Apesar de sombreado, ele não protege os garimpeiros do calor. O barracão não conta com banheiro, possui um forno a lenha desativado, uma mesa e dois bancos compridos, mas a maioria dos garimpeiros come no chão. Mesmo considerando que os garimpeiros estão "acostumados" com essa situação, parece desejável que o projeto busque melhorar as condições no local.

\section{Questões ambientais}

Apesar dos garimpos da cooperativa e de alguns garimpos autônomos terem obtido as licenças ambientais, ainda ocorrem práticas que não estão em conformidade com a regulamentação. Dois aspectos parecem ser mais relevantes: o impacto sobre os recursos hídricos e a recuperação das áreas degradadas.

O garimpo de Boi Morto localiza-se acima do riacho do Miguel, um afluente do rio dos Matos que abastece pequenos produtores rurais e duas outras cidades a jusante (Lagoa de São Francisco e Piripiri). No passado recente, houve casos do rejeito da mineração não ter sido disposto de forma adequada, sendo carreado para o riacho do Miguel, prejudicando as populações rurais. Quando ocorreu esse acidente, alguns moradores precisaram recorrer ao Ibama para que ele notificasse os garimpeiros. Atualmente, esse risco parece ter sido minimizado com a construção de uma barreira de contenção entre a mina e o rio. Na região do garimpo da Roça, o rio já teve seu curso modificado diversas vezes pela ação dos garimpeiros.

O segundo problema relativo à questão ambiental é a recuperação das áreas degradadas. Atualmente, o rejeito da mina de Boi Morto vem sendo usado para recompor as cavas abertas. Entretanto, como forma de aumentar a renda dos garimpeiros, vem sendo estudada a utilização desse material na elaboração de agregado para a construção civil. Caso essa alternativa se mostre tecnica e economicamente viável, será preciso que se desenvolvam outras estratégias para a recuperação da área.

Outra questão relacionada à recuperação da área do garimpo de Boi Morto diz respeito ao reflorestamento. Os principais empecilhos parecem ser a falta de pessoal e a constante invasão das cabras que comem as mudas. A cooperativa também possui um viveiro de mudas, mas ainda não iniciou as atividades de reflorestamento. No garimpo da Roça não parece haver plano de recuperação e o local encontra-se altamente degradado. Aparentemente, essa questão ainda não parece ser considerada uma prioridade pelos garimpeiros, devendo ser mais discutida pela equipe do APL e pelos órgãos ambientais. 


\section{Valorização da opala no mercado}

Até o final dos anos 1990, a maior parte das opalas de Pedro II era vendida em sua forma bruta, ainda com pouco valor agregado. A partir de então, esforços foram feitos para desenvolver atividades locais de beneficiamento das gemas, que resultaram em uma série de oficinas de lapidação e joalheria na cidade. Entretanto, as melhores opalas parecem ainda ser vendidas para fora de Pedro II, no estado bruto, sendo lapidadas na região Sudeste ou fora do país. Assim, mais iniciativas são necessárias para aprimorar a qualidade da lapidação local.

A maior parte dos lapidários de Pedro II foi treinada na própria cidade, tendo os mesmos professores. Assim, todos têm conhecimento semelhante e dominam, fundamentalmente, as mesmas técnicas. Por esse motivo, parece ser importante, sem interromper os treinamentos até o momento desenvolvidos, atrair outros profissionais para oferecerem cursos de aperfeiçoamento em lapidação e joalheria. Outra iniciativa necessária é uma maior divulgação da opala no mercado nacional e o fortalecimento da "marca" Pedro II. Para tanto, parecem ser necessários trabalhos em duas frentes: na produção e na divulgação. Quanto à produção é fundamental um trabalho junto a lapidários e joalheiros com relação ao controle de qualidade e ao aumento da diversidade do design das peças, de forma a melhorar a aceitação por consumidores mais exigentes. Do ponto de vista da ampliação de mercado, uma estratégia que vem sendo negociada pelos atores do APL é a indicação geográfica (IG) para as opalas de Pedro II. A IG é a criação de uma identidade para um produto específico, que dá a esse produto um diferencial de mercado e possibilita aos produtores cobrarem um "preço prêmio" por essa diferença. Exemplos de IG no Brasil são a carne do pampa gaúcho e o café do cerrado mineiro.

\section{Reflexões para políticas públicas}

\section{Evitando o ciclo boom-colapso: o turismo como alternativa}

Localidades que buscam desenvolvimento econômico baseado em recursos não-renováveis, como minerais e combustíveis fósseis, precisam sempre enfrentar o seguinte desafio: como se preparar para quando os recursos acabarem?

A literatura econômica trata desse problema através da tese da "maldição dos recursos", segundo a qual, os investimentos em grande escala nas atividades mineradoras e o rápido capital obtido com as vendas dos produtos levam a um ciclo vicioso de concentração das atividades econômicas (DAVIS, 1995). Dependendo do grau de concentração, pode haver um esvaziamento de outros setores e o aumento da dependência da indústria mineral. Entretanto como esses recursos não são renováveis, uma vez que se tornem indisponíveis, a economia local tende a se retrair.

A maldição dos recursos não deve ser encarada como algo inevitável e pode ser solucionada com políticas públicas preventivas, que, ao invés de buscar ganhos de curto prazo, utilizem os recursos obtidos com a mineração para subsidiar o desenvolvimento de outras atividades que serão mais rentáveis no longo prazo. Normalmente, no Brasil, empresas e governos têm uma visão de curto prazo, que gera os chamados "ciclos de boom-colapso". Alguns exemplos desses ciclos na história do Brasil são a cana de açúcar, no Nordeste, o ouro, em Minas Gerais, e o café, no Vale do Paraíba do Sul. Um exemplo mais atual desse processo foi a exploração de manganês na Serra do Navio (Amapá). Nessa localidade, a empresa Indústria e Comércio de Minérios S/A (Icomi) montou uma ampla infra-estrutura para exploração do minério, incluindo mina, usina de beneficiamento, porto, estrada de ferro e vilas. Entretanto, depois que as reservas foram exauridas, a empresa fechou a mina, sem ter preparado a cidade para isso. Além de criar uma série de problemas ambientais (minas abertas, contaminação de solo e água por arsênio etc.), nem a empresa, nem a administração local se preocuparam com o destino das pessoas que ali trabalhavam. Ao longo do tempo, a população vem migrando para outras localidades e as vilas estão se transformando em cidades fantasma (BARRETO, 2001).

Com relação a Pedro II, o caso da Emibra poderia também ser associado a um ciclo boom-colapso. Porém, o projeto APL vem tentando evitar que um processo semelhante ao das décadas de 1960/1970 ocorra, e as instituições envolvidas tentam desenvolver outros setores, dos quais o mais promissor parece ser o turismo. 
Conforme mencionado anteriormente, Pedro II tem uma vocação natural para o turismo, devido à sua altitude e clima ameno. Além disso, a cidade possui alguns atrativos naturais, como a Serra do Gritador e a Cachoeira do Salto Liso, que funcionam como pólos atrativos de ecoturismo. Entretanto, o turismo não vem se desenvolvendo apenas pelos atrativos próprios da cidade, existindo também ações por parte de organizações públicas e privadas. Nesse sentido, uma das principais experiências da cidade é o Festival de Inverno que, em 2007, atraiu aproximadamente 10 mil turistas para Pedro II (DUARTE, 2006; PRADO, 2007).

Embora não deva ser encarada como panacéia, a opção pelo investimento em turismo em Pedro II parece estar produzindo resultados positivos. Deve-se levar em conta que a cidade consegue combinar atrativos culturais e naturais e que se localiza numa região carente de opções de lazer e turismo. Apesar de não se apresentar, ainda, como um substituto para a mineração, o turismo vem conseguindo dinamizar um pouco mais a economia local e aumentar a renda da população.

\section{A necessidade de maior articulação entre órgãos de licenciamento}

No que se refere ao licenciamento para as atividades de mineração, parece necessário que haja uma maior cooperação e articulação entre os órgãos públicos. Essa necessidade diz respeito aos diferentes órgãos ambientais e à relação destes com os órgãos do setor mineral.

A análise dos processos de licenciamento de algumas minas sugere uma má gestão pública e treinamento insuficiente dos técnicos, tanto no âmbito estadual quanto federal. Tais situações são prejudiciais tanto para o Estado, devido ao dinheiro desperdiçado em processos incorretos, quanto para as empresas, que levam mais tempo para iniciar suas atividades e gastam recursos em atividades desnecessárias. Essa realidade termina, ainda, por desestimular a formalização das atividades, uma vez que pequenos empresários acabam preferindo atuar na informalidade e correr o (baixo) risco de multas a ter que passar por um processo tão lento e custoso.

Outra questão decorrente da análise dos processos de licenciamento é a aparente distância entre os setores mineral e ambiental. Os diferentes órgãos parecem seguir políticas totalmente distintas e não trocar muita informação (BARRETO, 2001), criando uma série de sobreposições. Nesse sentido, poderia ser proveitoso o desenvolvimento de procedimentos integrados e compatíveis para o licenciamento ambiental de atividades minerais (MACEDO et al, 2003).

Uma ação conjunta entre o setor meio ambiente e o setor mineral poderia, inclusive, possibilitar uma maior aproximação de garimpeiros e pequenos mineradores com o setor ambiental, levando a uma maior formalização das atividades. Cabe observar que a partir de conversas com garimpeiros foi possível identificar uma visão bem distinta com relação ao DNPM e ao Ibama/Semar. Na visão dos garimpeiros, o DNPM é um aliado que deseja "movimentação de terra" e "quer tirar opala"; por outro lado, o meio ambiente "atrapalha" porque "não quer que mexam no terreno". Talvez, uma parceria entre os dois setores diminuísse a visão negativa quanto aos órgãos ambientais, ampliando o diálogo com os produtores.

\section{Mercado informal e evasão de impostos}

Conforme argumentado na parte inicial deste artigo, uma parte significativa da cadeia de gemas se desenvolve na informalidade. Isso se deve não apenas às características das gemas em si (alta mobilidade e difícil valoração), como também por aspectos dos trabalhadores envolvidos em sua exploração (pessoas de baixa renda, com poucos estudo e acesso limitado à informação). A informalidade do garimpo e do comércio de gemas gera uma série de situações indesejáveis, tais como condições precárias de trabalho, exploração de mãode-obra e uso demasiado de infra-estrutura urbana sem o devido retorno tributário.

Como não poderia deixar de ser, parte considerável da comercialização de opala em Pedro II ocorre de forma informal. Nem as cooperativas, nem a maioria dos joalheiros emitem ou exigem regularmente notas de venda das pedras. Quando algum comprador faz essa solicitação, é comum o vendedor recorrer à Secretaria Municipal de Fazenda e emitir uma nota avulsa. Além disso, alguns comerciantes legalizam suas pedras para poderem participar de exposições ou quando exportam jóias para clientes que desejam seguir os procedimentos corretos. 
Em teoria, municípios como Pedro II, onde o garimpo e a mineração são tão relevantes para a economia local, deveriam ser locais de fácil controle sobre as atividades de comércio de gemas. Entretanto, para um controle eficiente seria necessária uma participação intensa do município, o que raramente se verifica. Essa ausência do poder local ocorre principalmente porque, do ponto de vista dos prefeitos, eles têm mais a perder do que a ganhar ao exigirem que a lei seja comprida.

Entre os impostos que incorrem sobre a comercialização de pedras para o mercado doméstico, um dos mais significativos é o Imposto sobre Circulação de Mercadorias e Serviços (ICMS). Porém, apenas uma parte menor dele é destinada para o município. Além disso, as pedras que são diretamente exportadas são isentas de ICMS. Dessa forma, o retorno tributário para o município a partir do comércio de pedras e jóias é relativamente pequeno.

Outra possível fonte de arrecadação é a Compensação Financeira pela Exploração de Recursos Minerais (CFEM). A CFEM para pedras preciosas e coradas lapidáveis (como no caso da opala) é de 0,2\% do faturamento líquido obtido pela venda do mineral. Embora 65\% da CFEM sejam destinados ao município, o valor é muito baixo em termos absolutos para cidades onde existem pequenos garimpos. Em 2006, somente $\mathrm{R} \$ 127,81$ foram arrecadados pelo município com a CFEM de opalas.

Do ponto de vista dos prefeitos, eles têm muito a perder politicamente se tentarem realizar um controle ostensivo do comércio de pedras: o chamado pacto com o diabo (TENDLER, 2002). Uma parte significativa da população tem relação direta ou indireta com a exploração e o comércio de gemas e se sentirá afetada de forma negativa. Ao mesmo tempo, o retorno financeiro para o orçamento municipal é muito baixo, não parecendo justificar as perdas políticas. Como muitas vezes é o município que arca com os custos para remediar os impactos sociais e ambientais, é previsível que parte significativa da tributação sobre a exploração mineral seja transferida para o governo local. Entretanto, a CFEM parece não estar contribuindo de forma eficaz para essa transferência, sendo necessária a adaptação desse instrumento.

\section{Alguns desafios para o projeto APL}

Como última questão, fazemos aqui algumas reflexões sobre a validade do projeto APL desenvolvido em Pedro II, que podem ser usadas em projetos futuros. Dois questionamentos principais são apresentados: (1) como fortalecer a cadeia como um todo; e (2) quais atividades devem ser escolhidas como prioritárias.

Com relação ao primeiro ponto, o exemplo de Pedro II mostra que o APL conseguiu fortalecer a cadeia da opala, mesmo de forma desigual. As informações obtidas sugerem que lapidadores, joalheiros e comerciantes têm um poder de barganha muito superior ao dos garimpeiros. Não está claro se essa situação foi criada deliberadamente ou de forma acidental; mas os garimpeiros parecem ter ganhado muito pouco com o projeto, trabalhando ainda em condições muito precárias, por um pagamento baixo diante do esforço que realizam. Os dados disponíveis não permitem identificar se houve alguma melhoria relativa. Talvez, "antes fosse muito pior". Porém, há fortes indícios de que os ganhos do projeto não vêm sendo distribuídos de forma equilibrada.

Ao mesmo tempo, se o projeto APL buscar fortalecer explicitamente a cooperativa de garimpeiros, esses poderiam contatar lapidadores de outras regiões, enfraquecendo o comércio local que vem sendo desenvolvido. Portanto, em situações onde o mercado é tão limitado com no caso da opala, parece ser um grande desafio manter o equilibro entre os diferentes elos da cadeia produtiva.

Um segundo questionamento com relação ao projeto APL opala diz respeito à ordem das atividades realizadas. Em sua primeira fase, o projeto investiu recursos na melhoria das condições de trabalho de garimpeiros e artesãos, na legalização das atividades e na comercialização dos produtos. Em uma segunda fase, o projeto prevê realizar o mapeamento e a sondagem das principais jazidas de opala.

Ao vermos o projeto como um todo, percebemos que ele foi realizado de trás para frente. Como a opala é um recurso não-renovável já explorado em grande quantidade, parece que seria mais lógico, primeiro, fazer o estudo da disponibilidade das gemas, para que, então, se avaliasse a viabilidade de investimento de recursos na 
exploração do setor. Agora, o projeto corre o risco de, após três anos de trabalho, descobrir-se que a extração de opala não é economicamente viável e que, portanto, toda a infra-estrutura montada poderá ficar subutilizada.

Aparentemente, os técnicos do projeto APL definiram seu cronograma de atividades buscando priorizar os problemas mais urgentes. Provavelmente, quando iniciaram o projeto eles se defrontaram com garimpeiros proibidos de trabalhar ou fazendo-o de forma muito precária. Ante tal situação, consideraram os demais aspectos do projeto (como a quantificação das reservas existentes) uma questão secundária. Apesar de a iniciativa ter sido louvável, pode ser que tal decisão tenha levado o APL a apenas minimizar os problemas imediatos, sem resolvê-los no longo prazo.

\section{Comentários finais}

Através de uma descrição histórica, buscou-se apresentar como se configurou a situação atual da produção e do comércio de opalas em Pedro II. Essa formação pode ser associada a um longo processo de ausência do poder público, quando empresas e garimpeiros atuaram sem nenhum controle efetivo da extração ou da comercialização de gemas. Como decorrência dessa dinâmica, o município e a população local não se apropriaram das riquezas geradas, vivenciando algo próximo a um ciclo boom-colapso. Portanto, essa experiência reforça o argumento de que as atividades do setor mineral precisam ser acompanhadas de perto pelos órgãos ambientais e minerais.

Como tentativa para remediar a situação, parcerias vêm sendo realizadas entre poder público e iniciativa privada. Nesse sentido, o projeto APL tem o mérito de tentar construir uma agenda propositiva pela qual soluções são encontradas a partir de esforços conjuntos. Um segundo aspecto positivo do projeto é o fato de estar atuando em uma área muito carente do país, que sofre com a constante emigração de pessoas. O total de pessoas beneficiadas pelo projeto não é claro, mas as estimativas sugerem 400 empregos diretos e indiretos gerados (PINTO; FEITOSA, 2007). Independente do número de beneficiados, parece claro que o projeto APL contribui para a manutenção de pessoas em Pedro II e para a dinamização da economia local. Os ganhos econômicos mais imediatos se referem à comercialização das pedras, mas ainda há o potencial do turismo que vem sendo desenvolvido.

No entanto, o projeto ainda terá de enfrentar desafios. Algumas questões, como as condições de trabalho e a mitigação dos impactos ambientais, embora não sejam de simples solução, são passíveis de melhorias, condicionadas, basicamente, pela dependência de recursos humanos e financeiros, bem como de vontade política. Outras questões, porém, parecem exigir reflexões mais profundas por parte dos membros do projeto, entre essas estão a busca do equilíbrio de forças entre os diferentes elos da cadeia produtiva e a criação de alternativas econômicas no caso dos estudos geológicos mostrarem que a exploração de opalas não é mais economicamente viável em Pedro II.

Por fim, o caso de Pedro II levanta algumas questões que vão além do projeto APL e que, necessariamente, devem ser levadas a outros grupos envolvidos com o tema mineração. Com relação a esse grupo de problemas, parece necessário rediscutir a tributação das atividades minerais (em particular, a função do CFEM) e o redesenho dos procedimentos de licenciamento de atividades minerais (buscando a integração entre o licenciamento mineral e o ambiental). 


\section{Referênclas}

ALI, S. H. Mining, the environment and indigenous development conflicts. Tucson, AZ (EUA): University of Arizona Press, 2003.

ALTEMBURG, T.; MEYER-STAMMER, J. How to promote clusters: policy experiences from Latin America. World Development, v.27, n.9, p.1693-1713, 1999 .

AMORIM, M. A. Clusters como estratégia de desenvolvimento industrial no Ceará. Fortaleza: Banco do Nordeste, 1998.

BARRETO, M. L. (Ed.). Mineração e desenvolvimento sustentável: desafios para o Brasil. Rio de Janeiro: Cetem/MCT, 2001.

BATISTA, D. Pedro Il decreta estado de emergência devido à seca. Meio Norte, Teresina, 20 out. 2005. Município, p.7.

BATISTA, G. Famoso designer de jóias vem a Pedro II. Agência Sebrae de Notícias - Piauí. 3-6-2007. Disponível em: <http://sebraepi.interjornal.com.br/noticia.kmf?noticia=6156359\&canal=250>. Acessado em: 13 set. 2007.

BNDES et al. Pesquisa gestão ambiental na indústria brasileira. Brasília: BNDES, 1998.

BRASIL. Lei $n^{\circ} 7.805$, de 18 de julho de 1989. Altera o Decreto-Lei no 227 , de 28 de fevereiro de 1967 , cria o regime de permissão de lavra garimpeira, extingue o regime de matrícula, e dá outras providências. Diário Oficial da União, Brasília, DF, 20 jul 1989.

Disponível em: <http://www.planalto.gov.br/ccivil/Leis/L7805.htm>. Acessado em: 24 out. 2007.

CETEM. Extração racional vai garantir ciclo da opala. Cetem na mídia, 24-7-2005. Disponível em: <http://www.cetem.gov.br/cetem_midia2005.htm>. Acessado em: 9 set. 2007.

COHEN, M.J. Sustainable development and ecological modernisation: national capacity for rigorous reform. Oxford: Oxford Centre for the Environment, Ethics \& Society, 1997.

COOGP. Estatuto social da cooperativa dos garimpeiros de Pedro II - COOGP. Aprovado em assembléia geral realizada em 12 jun. 2004. Pedro II, 2004. Mimeografado.

DAVIS, G. Learning to love the Dutch disease: evidence from the mineral economies. World Development, v.23, n.10, p.1765-1779, 1995.

DNPM. Portaria $\mathrm{n}^{\circ}$ 29, de 8 fev. 2007a. Disponivel em: <http://www.dnpm.gov.br/conteudo.asp?IDSecao=67\&IDPagina=84\&IDLegislacao=450>. Acessado em: 24 out. 2007.

Cadastro mineiro. 2007b. Disponível em: <https://sistemas.dnpm.gov.br/sicom>. Acessado em: 11 out. 2007.

DUARTE, R. B. A. Histórias de sucesso - comércio e serviços: turismo. Brasília, DF: Sebrae, 2006.

FINEP: Convênio ref. 3686/04. Rio de Janeiro, 2005. Mimeografado.

FUNDAÇÃO CEPRO. Diagnóstico e diretrizes para o setor mineral do estado do Piauí. Teresina: Fundação Centro de Pesquisas Econômicas e Sociais. 2005 .

GARIMPEIROS têm licença para extrair opala. Meio Norte. Teresina, 24 jul. 2005. Economia, p.6.

GOULART, S. Uma abordagem ao desenvolvimento local inspirada em Celso Furtado e Milton Santos. Cadernos Ebape.BR., v.4, n.3, 2006. Disponível em: <www.ebape.fgv.br/cadernosebape>.

HENRIQUES, H. S.; SOARES, M. M. (Coord.). Políticas e ações para a cadeia produtiva de gemas e jóias Brasília, DF: IBGM. 2005.

HILSON, G. (Ed.). Socio-economic impacts of artisanal and small-scale mining in developing countries. Lisse: A. A. Balkema Publishers, 2003.

HILTON, J. J. et al. Clean artisanal gold mining: a utopian approach? Journal of Cleaner Production, v.11, p.99-115, 2003.

IBGE. Pesquisa de inovação tecnológica. Rio de Janeiro: IBGE. 2005.

IBGM. O setor de gemas e metais preciosos em grandes números. 2006. Disponível em: <http://www.ibgm.com.br/>. Acessado em: 1 set. 2007. 
IPIRANGA, A. S. R. Uma discussão teórica sobre aprendizagem, inovação e cultura nos arranjos e sistemas produtivos territoriais. Cadernos Ebape.BR, v.6, n.2, 2008. Disponível em: <www.ebape.fgv.br/cadrnosebape>.

IPIRANGA, A. S. R. et al. Tecnologia social para arranjos produtivos locais: uma proposta de aplicabilidade. Cadernos Ebape.BR, v.5 n.3, 2007. Disponível em: <www.ebape.fgv.br/cadrnosebape>.

JANSEN, P. Artesanato local alavanca economia de Pedro II. O Dia, Teresina, 30 maio 2005. Economia, p.1.

A vida além das opalas. O Dia, Teresina, p. 4. 27 maio 2007.

LASTRES, H. M. M. et. al. (Org.). Pequena empresa: cooperação e desenvolvimento local. Rio de Janeiro: Relume Dumará Editora, 2003.

MACEDO, A.B. et al. Environmental management in the Brazilian non-metallic small-scale mining sector. Journal of Cleaner Production, v.11, p.197-206, 2003.

MIRANDA, J. G., et al. Atividades garimpeiras no Brasil: aspectos técnicos, econômicos e sociais. Rio de Janeiro: MCT, 1997. (Série Estudos e Documentos. n.38).

MOL, A. P. J. Ecological modernisation and institutional reflexivity: environmental reform in the late modern age. Environmental Politics, v.5, n2, p.302-323, 1996.

NEALE, A. Organising environmental self-regulation: liberal governmentality and the pursuit of ecological modernisation in Europe. Environmental Politics, v.6, n.4, p.1-24, 1997.

OISHI, S.M. How to conduct in-person interviews for surveys. Thousand Oaks, CA: Sage Publications, 2002.

OLIVEIRA, J. C. Recursos gemológicos dos estados do Piauí e Maranhão. Teresina: CPRM, 1998.

; CARDOSO, C. E. T. Projeto opala em Pedro II: relatório final. Recife: CPRM, 1979. v.1.

OLIVEIRA, J. F.; SOARES FILHO, A. R. Garimpos de opalas da região de Pedro II, PI. Avulso. Departamento nacional da produção mineral, Brasília, DF, n.5, p.121-36, 1983 .

OPALAS NORDESTE. Opala, a nossa maior riqueza. Disponivel em: <http://www.opalasnordeste.kit.net/index_arquivos/historia.htm>. Acessado em 26 out. 2007.

PINTO, D. A. M.; FEITOSA, R. N. A. Relatório Pedro II. Pedro II, 2007. Mimeografado.

PNUD. Atlas do desenvolvimento humano no Brasil. Programa das Nações Unidas para o Desenvolvimento - PNUD. 2003. Disponivel em: <http://www.pnud.org.br/atlas/>. Acessado em: 25 out. 2007.

PRADO, S. Festival consolida-se como evento de sucesso. Agência Sebrae de Notícias Piauí. 10-6-2007. Disponível em: <http://sebraepi.interjornal.com.br/noticia.kmf?noticia=6175906\&canal=250>. Acessado em: 13 set. 2007.

RINKEVICIUS, L. The ideology of ecological modernization in 'double-risk' societies: a case study of Lithuanian environmental policy. In: SPAARGAREN, G.; MOL, A. P. J.; BUTTEL, F. H. (Ed.). Environment and global modernity. London: Sage, 2000.

SCHMITZ, H. Small shoemakers and fordist giants: tale of a super cluster. World Development, v.23, n.1, p.9-28, 1995.

; NADVI, K. Clustering and industrialization: introduction. World Development, v.27, n.9, p.1503-1514, 1999.

SICSÚ, A. B.; LIMA, J. P. R. A pequena mineração no nordeste - suas características e o papel do estado. Rio de Janeiro. [s.n.], 1991. p.9-26. (Série Estudos e Documentos, n. 12).

SILVA, A. V.; DEMAJOROVIC, J. Arranjos produtivos locais e responsabilidade socioambiental: uma análise do pólo moveleiro de Arapongas. In: ENCONTRO DA ASSOCIAÇÃO NACIONAL DE PÓS-GRADUAÇÃO E PESOUISA EM ADMINISTRAÇÃO, 32., 2008, Rio de Janeiro. Anais... Rio de Janeiro: [s.n.], 2008.

SOUZA, V. C. Perfil analítico da opala. Brasília, DF: DNPM, 1985. 49p. (Boletim DNPM, 58). 
TEIXEIRA, N. S.; LIMA, M. H. R. Características e atuação das organizações de garimpeiros no Brasil. Anais da XII Jornada de Iniciação Científica. Rio de Janeiro: Cetem. 2004. Disponível em: < http://www.cetem.gov.br/serie anais XII_jic.htm>. Acessado em: 31 ago. 2007.

TENDLER, J. Small firms, the informal sector and the devil's deal. IDS Bulletin [Institute of Development Studies], v.33, n.3, July 2002.

VEIGA, M. M. Mining with communities. Natural Resources Forum, v.25, p.191-202, 2001.

WEISS, R. Learning from strangers: the art and method of qualitative interview studies. New York, NY: Free Press, 1995.

YIN, R. Case study research: design and methods (Applied social research methods series, v.5). Thousand Oaks: Sage Publications, Inc., 1994.

YOUNG, S. C. Introduction: the origins and evolving nature of ecological modernisation. In: YOUNG, S. C (Ed.). The emergence of ecological modernisation: integrating the environment and the economy? London; New York: Routledge, 2000. 